\title{
Theory of Planned Behavior to Analyze the Intention to Use the Electronic Money
}

\author{
Shabrina Prayidyaningrum* \\ MD Djamaludin \\ Department of Family and Consumer Sciences, \\ Faculty of Human Ecology, \\ Bogor Agricultural University \\ Department of Family and Consumer Sciences, \\ Faculty of Human Ecology, \\ Bogor Agricultural University \\ *Corresponding author: sprayidyaningrum@gmail.com
}

\begin{abstract}
This study aimed to analyze the knowledge, attitude, and purchase intention on electronic money among undergraduate students approached by the Theory of Planned Behavior (TPB). The study involved 100 undergraduate students of Bogor Agricultural University (IPB) which were selected randomly. The design of the study was cross sectional study with simple random sampling method. The results showed that attitude and intention to use was the high category, while the greatest proportion of subjective norm and behavioral control were at the middle category. Meanwhile, according to the model of Theory of Planned Behavior (TPB), attitude, subjective norm, and behavioral control had positive correlations with intention to use e-money. Attitude and subjective norm affected intention to use e-money.
\end{abstract}

Keywords: electronic money, intention to use, Theory of Planned Behavior (TPB)

\begin{abstract}
Abstrak. Tujuan penelitian ini adalah untuk mengidentifikasi sikap, norma subjektif, dan kontrol perilaku pembentukan intensi penggunaan uang elektronik pada kelompok mahasiswa IPB Menggunakan Pendekatan Theory Of Planned Behaviour. Penelitian ini melibatkan 100 mahasiswa strata 1 (S1) Institut Pertanian Bogor yang diambil secara acak. Desain penelitian ini adalah cross sectional study. Hasil penelitian menunjukkan bahwa sikap dan niat menggunakan contoh berada pada kategori tinggi, sedangkan proporsi terbesar norma subjektif dan kontrol perilaku terhadap uang elektronik berada pada kategori sedang. Hasil penelitian menunjukkan adanya hubungan antara karakteristik individu yaitu uang saku dengan niat menggunakan serta adanya hubungan antara sikap, norma subjektif, dan kontrol perilaku dengan niat menggunakan uang elektronik. Hasil uji regresi menunjukkan bahwa sikap dan norma subjektif berpengaruh terhadap niat menggunakan uang elektronik.
\end{abstract}

Kata kunci: niat menggunakan, theory of planned behavior (TPB), uang elektronik 


\section{Introduction}

E-money was first coined in 1990 by the company "DigiCash" founded by the encryption expert David Chaum. Based on some of the benefits of e-money, it provides convenience and speed in the transaction, do not receive the money returns in the form of goods, and very applicable to bulk transactions with small value but high frequency. E-money can be used in various places such as minimarkets, supermarket, toll roads, to pay the electric bill, public transportation (trans jakarta), and so forth.

The development of e-money in Indonesia is indeed significant. According to the Bank Indonesia, the value of transactions using electronic money in 2012 reached Rp1.97 trillion or increased of 101.02 percent over the previous periode of Rp981,30 billion (BI, 2012). On the other hand, based on data from the Bank for International Settlements (BIS), in 2012 the number of e-money transaction for Singapore was 3.015.1 billion US dollars and Japan amounted to 2.000.4 billion US dollars. However, Indonesia's transactions are considered small compared with the two countries as its population is much larger.

In order to encourage non-cash transactions the government made an effort called the National Movement for Non-Cash, also known as GNNT. GNNT was officially launched by the Governor of Bank Indonesia in 2014. Based on the Act of the Republic of Indonesia Number 23 of 1999 concerning Bank Indonesia as amended by the Act Number 3 of 2004, Bank Indonesia's tasks in the field of payment systems include a system of cash and non-cash payments. Bank Indonesia has a big duty and is responsible for issuing rupiah in considerable amounts, furthermore Indonesia is a large archipelago country. The amount of cash in circulation poses various risks such as the high cost of landing cash, theft, health problems, and the emergence of counterfeit money (Hidayat et al., 2006). "Seen from the perspective of the economy broadly, the use of cash in a very large amount in the long run would pose a burden for the economy, especially related to cash handling and the low velocity of money". In addition, the use of cash in public facilities has also resulted in long queues as cash require a longer time transaction.

Since the beginning of 2000, a lot of studies on e-money have been started specifically on credit cards and debit cards while the ones focus on prepaid products have not been widely applied. Studies on knowledge, attitudes and intentions establishment of the use of e-money are of important aspects to be carried out as prior studies have Given that one of the aspects that will affect consumers in making the decision to use or consume a product is knowledge and attitude. Consumer knowledge is all the information held by consumers on a wide range of products and services, as well as other knowledge related to such products and services, and information related to its function as a consumer. Engel, Blackwell, and Miniard (1994) divides consumers into three kinds of knowledge: (1) knowledge of the product, (2) knowledge of the purchase, (3) the use of knowledge.

When consumers have more knowledge, then the consumer will be better in making decisions, consumers will be more efficient and more precisely manage information better. In general, consumers with the higher knowledge of product have a better a memory, recognition, analysis and logic ability than those who 
have knowledge of an inferior product. While the attitude is studying the tendency to respond to an object either liked or not liked consistently. Attitude is a mental and neural connection with the readiness to respond, organized through experience and has a direct influence and / or dynamic on behavior. Besides that, knowledge and attitude will also affect the level of use of the product. It's important to know the group's knowledge of IPB students about e-money and the attitude in the use of e-money. Bank Indonesia is trying to realize the National Movement of Non-Cash (GNNT) by doing some cooperation including cooperation with the college. This is done because the college student is considered as a group in society owned high intellectual and is expected to help create the National Movement of Non-Cash (GNNT).

\section{Review Literature}

Bank for International Settlements (1996) define e-money as the product stored-value or prepaid with stored value for money in the electronic equipment. E-money become a multifunctional payment tool

Theory of Planned Behavior is the development of the Theory of Reasoned Action by the addition of behavioral control as a determinant of perceived behavioral control where control belief affects the perceived behavioral control (Chang, 1998). Theory of Planned Behavior is based on the assumption that humans are rational and use the information that may be for him systematically (Achmat, 2011). People thought the implications of their actions before they decide to do or not to do certain behaviors. Model Theory of Planned Behavior (TPB) became a basic reference framework of the development of this research. In accordance with the Theory of Planned Behavior, there are several variables that influence an individual's decision in the decision making to use emoney. The concept of attitude is closely related to the concept of trust (belief) and behavior (behavior).

Consumer confidence is the consumer's knowledge of an attributes object and its benefits (Mowen and Minor, 1998). Consumer's confidence or knowledge is the confidence that a product has a variety of attributes and benefits. This knowledge is useful in communicating the attributes of a product to consumers. Subjective norm is the individual's perception of the expectations of others (considered important) for showing or not showing a behavior (normative beliefs) and how much the desire of individuals to the expectations of the other person (motivation to comply). Meanwhile, the control behavior is a composite of individual trust level that he is able to control or indicate a behavior (control beliefs) and an individual's belief that there is a supporting or inhibiting factor in demonstrating the behavior (perceived power).

Meanwhile, two other variables, namely the characteristics of the students and families of students, allegedly influence the intention to use electronic money, either directly or indirectly. Some characteristics of the individuals tested in this study include age and pocket money. Meanwhile, the family environment, especially parents is an environment that is closest to the individual. Thus, family characteristics such as family size, and income per capita is also allegedly to have an influence on the intention of using. 


\section{Method}

\section{Participants}

This study was conducted at Bogor Agricultural University (IPB), Bogor, West Java, Indonesia. The location was selected purposively with consideration that IPB is one of universities that has held the Electronic Money (e-money) socialization in 2014 to realize the National Movement of Non-Cash (GNNT). Preliminary research had been completed to get a sample framework of population of IPB student using e-money totaling 212 students. Furthermore, the number of sample was determined using the Slovin's formula as follows:

$$
\mathrm{n}=\frac{\mathrm{N}}{\left(1+\mathrm{Ne}^{2}\right)}=\frac{212}{1+212(0.09)^{2}}=78
$$

Where:

$\mathrm{n}=$ number of sample

$\mathrm{N}=$ number of population

$e=$ error tolerance of 0.09

$1=$ constant value

Calculation using the Slovin's formula obtained the number of sample amounted to 78 people. However, in order to assure and prevent the reduction number of sample because of unexpected circumstances such as incomplete or non-returned questionnaires, this study chose sample size amounted 100 people who then were selected by convenience sampling method.

\section{Measurement}

Primary data consisted of student characteristics (age, gender, monthly allowance), family characteristics (family size, father's occupation, mother's occupation, father's education level, mother's education level, and parental income), attitude, subjective norm, and perceived behavioral control. The data collected through self-report techniques with questionnaires as the tool. Students were asked to directly fill in the questionnaires submitted by the researchers by means of recall. This study chose self-report techniques as it was considerably able to obtain more reliable answers compared to interview because the respondent may freely examine and answer the questions without any interference from the researcher.

The questionnaire used for the variables attitude was developed from Awwaliyah (2013), contained twelve statements consisting of six statements of behavioral beliefs and six statements of outcome evaluation with this reliability value of 0.710 . Subjective norm was measured using ten statements consisting of each five statements of normative belief and motivation to comply with the reliability value of 0.924 . Perceived control behavior consisted of both six statements of control beliefs and power of control factor with the reliability value of 0.614 . The intention to use e-money was measured using four items with reliability value of 0.664 statements.

Students and family characteristics were presented in the open-ended questions. Meanwhile, each statement on the questionnaires of attitude, subjective norm, behavioral control, and intention to use was rated on Likert scale with four 
ratings: strongly disagree (score 1), disagree (score 2), agree (score 3), and very agree (score 4).

\section{Analysis}

Data were analyzed using Microsoft Excel for Windows dan Statistic Program for Social Seciencies (SPSS) for Windows. The analysis included descriptive analysis, reliability test for instruments, correlation test, and regression test. Descriptive analysis was used to identify student characteristics (age, gender, monthly allowance, and hometown) and family characteristics (family size, father's occupation, mother's occupation, father's education level, mother's education level, and parental income). Meanwhile, correlation test was used to analyze the relationships between student and family characteristics, subjective norm, perceived behavioral control, and the intention to use. To analyze the factors influencing the intention to buy of the students, the multiple linear regression test was done.

\section{Sample Characteristics}

\section{Result}

The results of the study showed that the number of male students is 21 people and female students are 79 people. This is because in sampling technique used in this research is random sampling. Age students were in the range of 18-23 years. The amount of pocket money owned by students ranged from Rp500,000 to 3,000,000 with an average of Rp1.099.000 per month.

\section{Family Characteristics}

There are 50 percent of the families of students, including the small family category which comprised of one to five people, 44 percent categorized as being family is comprised of four to seven people, 6 percent included in the category of large family of more than seven people. Family income students were in the range of Rp500,000-Rp3.500.000 and an average of Rp7.993.406.

\section{E-Money Use}

The results showed that the most widely famous brand of electronic money (e-money) owned student is Flazz Card of 31 percent. Information regarding the first electronic money (e-money) that is used by the student is from a friend / family, namely by 34 percent. The transaction value of electronic money (emoney) students who used the largest proportion is in the range of Rp40,000 Rp10.001- i.e. by 53 percent. Frequency of use of electronic money (e-money) per month a student is in the range of less than three times the use of e-money within one month. Replenishment (top up) electronic money (e-money) per month student largest proportion is $<50,000$ that is equal to 45 per cent.

\section{Attitude}

The results showed that the majority of students has a positive attitude towards the use of e-money, both in terms of confidence in the behavior (behavioral belief) and evaluation of behavioral outcomes (outcome evaluation). This is shown in the 
majority of student response to the statements regarding the e-money scattered on the answers agree and strongly agree.

Tabel 1 Distribution of students answer based on the attitude item statement

\begin{tabular}{|c|c|c|c|c|}
\hline \multirow{2}{*}{ Question } & \multicolumn{4}{|c|}{ Response } \\
\hline & 1 & 2 & 3 & 4 \\
\hline \multicolumn{5}{|l|}{ Behavioral belief } \\
\hline Perform payment transactions using electronic money more secure & 0 & 15 & 73 & 12 \\
\hline If I use electronic money, I will make payments effective and efficient & 0 & 14 & 62 & 24 \\
\hline $\begin{array}{l}\text { I will get the convenience of payment or queue is shorter when using } \\
\text { electronic money }\end{array}$ & 2 & 16 & 46 & 36 \\
\hline $\begin{array}{l}\text { If I use electronic money, it will help reduce the burden of the state in } \\
\text { terms of printing money }\end{array}$ & 2 & 14 & 57 & 27 \\
\hline $\begin{array}{l}\text { If I use electronic money, then I will reduce the transmission of disease } \\
\text { through the banknote }\end{array}$ & 1 & 13 & 64 & 22 \\
\hline $\begin{array}{l}\text { If use electronic money, then I will participate in the realization of the } \\
\text { National Movement of Non-Cash (GNNT) }\end{array}$ & 0 & 9 & 71 & 20 \\
\hline \multicolumn{5}{|l|}{ Outcome evaluation } \\
\hline Doing a secure payment is important & 0 & 1 & 52 & 47 \\
\hline It is important to make a payment that is effective and efficient & 0 & 1 & 61 & 38 \\
\hline Get the convenience of payment or shorter queues less important & 10 & 17 & 46 & 27 \\
\hline Reduce the burden on the state in terms of the cost of printing money & 0 & 18 & 57 & 25 \\
\hline Reduce the transmission of disease through paper money is less important & 4 & 24 & 50 & 22 \\
\hline Participate in helping the National Movement of Non-Cash (GNNT) & 1 & 16 & 67 & 16 \\
\hline
\end{tabular}

Notes. 1 = strongly disagree; 2 = disagree; 3 = agree; 4 = strongly disagree

Almost all of the students stated the importance of the payment effective and efficient transaction (99\%) and believe that e-money is a form of payment that is effective and efficient and can reduce the transmission of disease through paper money $(86 \%)$. Similar proportions states that perform secure payment is important $(99 \%)$ and it can be achieved through the use of e-money transactions are believed to be safer than conventional forms of payment (85\%). The majority of students also expressed his intent to participate in helping the National Movement of NonCash (GNNT) (83\%). Based on the classification attitude towards e-money, the majority of students was classified in the high category $(70 \%)$. This indicates that in general the students in this study showed a good attitude and positive impact on the use of e-money as a means of payment transactions.

\section{Subjective Norm}

Results showed that friends and parents are the people who influence the student's decision to use e-money. More than half the students adhere to both the suggestion of using e-money (64\% and 60\%). Meanwhile, relatives, teachers and friends in this study have not been classified as influential individuals (significant other) because many of those who do not argue that students should use e-money. Overall, subjective norm students in the use of e-money are not so strong (77\%). Less than five percent of college students think strongly about the importance of the advice reference group (parents, teachers, friends, relatives and / or friends) to use e-money and stick to it. 
Tabel 2 Distribution of student answers based on behavior control statement items

\begin{tabular}{llccc}
\hline \multirow{2}{*}{ Question } & \multicolumn{3}{c}{ Response } \\
\cline { 2 - 5 } Normative belief & 1 & 2 & 3 & 4 \\
My parent argued, I should use e-money & 4 & 56 & 33 & 7 \\
Lecturer I think, I should use e-money & 4 & 63 & 32 & 1 \\
My best friend believes, I should use e-money & 4 & 32 & 64 & 0 \\
My relation argued, I should use e-money & 5 & 57 & 36 & 2 \\
My friend argued, I should use e-money & 5 & 41 & 53 & 1 \\
Motivation to comply & & & \\
I will follow the opinion of my parents to use the e-money & 3 & 37 & 57 & 3 \\
I would follow the opinion of my lecturer to use e-money & 4 & 54 & 42 & 0 \\
I will follow the opinion of my friends to use e-money & 4 & 32 & 63 & 1 \\
I will follow the opinion of my brother to use e-money & 4 & 48 & 45 & 3 \\
I will follow my friend's opinion for the use of e-money & 5 & 38 & 56 & 1 \\
\hline
\end{tabular}

Notes. 1 = strongly disagree; 2 = disagree; 3 = agree; 4 = strongly agree

\section{Behavioral Control}

The results showed that most students have the perception that the recharge (top-up) need enough money and not many stores can carry out transactions with e-money is a limiting factor in the use of e-money. Instead, students are also convinced that sufficient knowledge will benefit the use of e-money. The risk of using cash money and the flexibility of time are the driving factors of students in using e-money.

Table 3 Distribution of answers to students based on behavior control statement items

\begin{tabular}{|c|c|c|c|c|}
\hline \multirow{2}{*}{ Pertanyaan } & \multicolumn{4}{|c|}{ Respon } \\
\hline & 1 & 2 & 3 & 4 \\
\hline \multicolumn{5}{|l|}{ Power of control factor } \\
\hline Using electronic money is safer than using cash & 0 & 22 & 65 & 13 \\
\hline $\begin{array}{l}\text { Currently, I do not have enough money to top up (recharge) the electronic } \\
\text { money }\end{array}$ & 9 & 54 & 33 & 4 \\
\hline Having good knowledge about the benefits of using electronic & 0 & 17 & 78 & 5 \\
\hline Knowing the risks arising from the use of cash & 0 & 15 & 74 & 11 \\
\hline Knowing shop / where are already using electronic money & 5 & 28 & 57 & 10 \\
\hline Have sufficient time to select the electronic money product I would use & 0 & 2 & 35 & 63 \\
\hline \multicolumn{5}{|l|}{ Control belief } \\
\hline Be sure to use electronic money is safer than cash & 0 & 28 & 65 & 7 \\
\hline $\begin{array}{l}\text { It would be easy to top up (recharge) electronic money if you have } \\
\text { enough money }\end{array}$ & 1 & 8 & 75 & 16 \\
\hline $\begin{array}{l}\text { Encouraged to use electronic money if I know the benefits of electronic } \\
\text { money }\end{array}$ & 0 & 4 & 74 & 22 \\
\hline Risks due to use cash to encourage to use electronic money & 0 & 47 & 49 & 4 \\
\hline $\begin{array}{l}\text { Find it difficult to use electronic money, if you do not know the shop / } \\
\text { place anywhere that has implemented a payment using electronic money }\end{array}$ & 2 & 28 & 48 & 22 \\
\hline $\begin{array}{l}\text { Leisure time will give more opportunity to choose products of electronic } \\
\text { money to be used }\end{array}$ & 1 & 19 & 78 & 2 \\
\hline
\end{tabular}

Notes. 1 = strongly disagree; 2 = disagree; 3 = agree; 4 = strongly agree 
Most of the students perceived that they have sufficient knowledge of the benefits of using e-money and risks of using cash money. It shows a high strength to push using e-money. Based on the category, control the behavior of students belongs to the moderate category $(78 \%)$. This indicates that the student has to believe and realize that there are a number of factors driving and inhibiting the use of e-money, but has not shown the power of control over those factors that are not strongly pointed to the behavior of the e-money using.

\section{Use Intention}

As with previous independent variables, the intention of using it was classified into three groups: low, medium and high by category. The results showed that the majority of students claimed to use e-money after having enough money and information. Moreover, they plan to allocate spending to replenish the e-money and intend to use it with security guarantees that exceed cash. Thus, more than half the students (59\%) showed high intention to use e-money

\section{Correlation between Sample and Family Characteristics, Attitude, Subjective Norm, Behavioral Control and E-Money Use Intention}

Based on the Theory of Planned Behavior, demographic characteristics of consumers have a relationship with the intention of using it. The results showed that the characteristic that affect the intention to use is the allowance $(r=-0203 ; p$ $<0.05)$. Thus, the higher the student allowance, the smaller the intention of using e-money. This is not in line with the research Adiyanti (2015) which states that the higher revenues will increase intent to transact uses e-money.

Intention can be said to be a motivating factor that affects a person's behavior, indicating how hard a person tries, how much effort they are planning to form a behavior (Ajzen, 1991). Intention is influenced by attitudes, subjective norms and behavioral control. These three variables are tested to see how big the correlation between these variables. Correlation test results in Table 5 shows the relationship between attitude with the intention of using $(r=0.477 ; p<0.05)$. This is consistent with research Beck and Ajzen (1991) and Harding et al. (2007) which stated that there is a significant relationship between the variables attitude with the intention of using.

Table 4 Relationship student characteristics, attitude, subjective norm, and control behavior with the intention of using e-money

\begin{tabular}{lc}
\hline Variable & Intention to use $e$-money \\
\hline Allowance & $-0.203^{*}$ \\
Attitude & $0.477^{* *}$ \\
Subjective Norm & $0.289^{* *}$ \\
Behavior Control & $0.432^{* *}$ \\
\hline
\end{tabular}

Notes. $(* *)$ significant at $\mathrm{p}<0.001$

Subjective norm with the intention of using show the correlation $(r=0289 ; \mathrm{p}$ $<0.05$ ), consistent with research Harding et al. (2007), Stone et al. (2007), and Kurningsih (2013). Behavior control is also positively associated significantly 
with the intention of using $(\mathrm{r}=0432, \mathrm{p}<0.05)$. This strengthens the research results Stone et al. (2007), Alleynez and Phillips (2011) and Yang (2012) which states that the behavior control variables significantly associated with the intention of using. Thus, the better attitude, subjective norm and behavioral control, it will be the higher the likelihood examples intend to use e-money.

\section{Factors That Influence E-Money Use Intention}

Results of regression analysis showed that the demographic characteristics of students and families do not significantly influence the intention to use emoney. On the other hand, the attitude $(\beta=0.503)$ and subjective norm $(\beta=0418)$ proved a positive influence on the intention to use e-money. That is a shift in attitude on the e-money in the positive direction will increase the likelihood of students for using e-money. Similarly, in subjective norm where students with many well as the growing influence of the reference group who suggested the use of e-money, students will be more likely to follow the recommendation and use of e-money. On the other hand, the control behavior showed no significant effect on the intention to use e-money. In overall, independent variables in regression models of this study explain 29.2 percent of the variance on the intention to use emoney, while the remaining 70.8 percent is likely influenced by other variables that not examined in this study.

Table 5 Multiple linear regression analysis on the student's characteristics, family characteristics, attitude, subjective norm, and control the behavior of the intention to use e-money

\begin{tabular}{|c|c|c|c|c|}
\hline \multirow[t]{2}{*}{ Free Variable } & \multicolumn{2}{|c|}{ Unstandardized Coefficient } & \multirow{2}{*}{$\begin{array}{c}\begin{array}{c}\text { Standardized } \\
\text { Coefficient }\end{array} \\
\text { Beta }\end{array}$} & \multirow[t]{2}{*}{ Sig. } \\
\hline & $\mathrm{B}$ & Std. Error & & \\
\hline Respondent age & -1.630 & 1.352 & -0.104 & 0.231 \\
\hline Pocket money & -2.327 & 0.000 & -0.109 & 0.246 \\
\hline $\begin{array}{l}\text { Number of family } \\
\text { member }\end{array}$ & 0,604 & 0.939 & 0,057 & 0.521 \\
\hline Family income & 8.840 & 0.000 & 0.043 & 0.624 \\
\hline Attitude & 0.503 & 0.129 & 0.358 & $0.000 * *$ \\
\hline Subjective norm & 0.418 & 0.176 & 0.236 & $0.020 *$ \\
\hline Behavior control & 0.072 & 0.083 & 0.082 & 0.387 \\
\hline $\mathrm{F}$ & & 6.830 & & \\
\hline Sig. & & 0.000 & & \\
\hline $\mathrm{R}^{2}$ & & 0.342 & & \\
\hline Adjusted R Square & & 0.292 & & \\
\hline
\end{tabular}

\section{Discussion}

In this study the characteristics of students with allowance have a negative correlation with the intention of using e-money while the family characteristics of the students do not have a relationship and a significant effect on the variable intention of using. This is not in line with the research Adiyanti (2015) which states that the higher revenues will increase interest in using e-money transactions. The brand of e-money, the most widely owned by students, is Flazz. 
Student attitudes towards the use of e-money are quite high. Statements about attitude, both representing confidence in the behavior (behavioral beliefs) and evaluating the behavioral outcomes (outcome evaluation), all responded positively, that is, instances have fairly high confidence that the use of e-money will provide significant benefits and deliver them to the desired objectives. The goals of transactions are safe and comfortable. It helps to reduce the burden of the state in terms of printing money, reduce disease transmission through the banknote, and participate in helping the National Movement of Non-Cash (GNNT).

Students also believe that if they use e-money, the payment transaction will be safe and efficient. This is similar with research of Ekaputra (2012) which states that the majority of consumers using e-money is that they want to make a payment safe and efficient. However, this is in contrast to research by Indriastuti (2014) which states that consumers using e-money is not due to the secure, but because consumer behavior wants to follow the trend of today.

Subjective norm is students' perceptions about whether people who are important to him think that he should use e-money. Subjective norm of 77 percent of students was in middle category, while 20 percent is in the low category and 4 percent is at the high category. Of the five social figures that allegedly would affect the example in the use of e-money are parents and friends who have the perception that students should use e-money. Engel, Blackwell and Miniard (1994) stated that a person's behavior is influenced by his family. In this case the parents play a fairly important though not living together with students. Taylor and Todd (1995) and Venkatesh and Davis (2000) said that subjective norm will affect people both directly and indirectly in using information technology.

Broadly speaking, the largest proportion of students who has control behavior was in middle category. Students believe that the possession of money, time discretion, knowledge about the benefits of using e-money, as well as risks rising from the use of cash money can encourage behavior using e-money. However, not knowing the shops/ places in which they have adopted the use of e-money payments into a common was the obstacle for students not to use e-money.

The results showed that more than half the students have the intention of using it included in high category. Students will use e-money if they already have the money and enough information about the product. This is presumably because there is still a lack of information about which merchants are now able to use emoney, and e-money card is expensive.

Some characteristics of individuals and families also have a significant relationship with attitude, subjective norm, and control behavior. Pocket money is negatively related to the intention to use e-money. This means that the higher the student allowance, the lower the intention to use e-money.

Results of regression analysis showed that among the characteristics and variables that have been in testing and affect the intention to use ate the attitude variable and subjective norm. This is similar with research of Taylor and Todd (1995) and Venkatesh and Davis (2000), which told the subjective norm will affect people both directly and indirectly. However, this is not similar with the research by Purnama (2012), which explains that the subjective norm has no effect on the use of e-money because someone using e-money transaction system was viewed easily and comfortably without having to be influenced by others. 


\section{Conclusion}

\section{Conclusion and Recommendation}

The results showed that the largest proportion of instances that has the attitude and intention of using e-money is the high category and most instances have control of behavior and the subjective norm with medium category. Parents and friends are considered as individuals who influence students to use electronic money, recharging requires enough money, yet many stores are using e-money transactions. There is a significant relationship between attitude, subjective norm, and control behavior with the intention of using e-money. However, behavioral control did not show any significant effect on the intention to use. Thus, the factors that can predict the intention of using e-money college students are the attitude and subjective norm.

\section{Recommendation}

From the analysis of the relationship between allowance and the intention of using e-money, students who have a high pocket money do not tend to use emoney, it is advisable to banking institutions so that the maximum balance improved electronic money in order to reach more layers of the economy. Yet many stores are implementing a payment system using e-money into one of the obstacles a person does not want to use it, it is advisable to increase the banking institution stores or public facilities that implement a payment system using emoney. Developing e-money technology in order to create an effective and efficient interoperability, as well as developing cooperation between the various parties, such as banks, financial institutions, merchants, and society needs to do further promoting the National Movement of Non-Cash.

\section{Reference}

Achmat, Z. (2011). Theory of planned behavior, still relevant ?. Available on http://zakarija.staff.umm.ac.id/files/2010/12/Theory-of-Planned-Behaviormasihkah-relevan1.pdf.

Adiyanti, A. I. (2015). Effect of income, benefits, ease of use, the appeal of promotion and confidence in the interest of using E-money services (Thesis). Malang: Brawijaya University.

Ajzen, I. (1988). Attitudes, Personality, and Behavior. Milton-Keynes, England: Open University Press \& Chicago, IL: Dorsey Press.

. (1991). The theory of planned behavior. Organizational Behavior and Human Decision Processes, 50 (2), 179-211.

Alleyne, P., \& Phillips, K. (2011). Exploring academic Dishonesty Among university students in Barbados: An estention to the theory of planned behavior. Acad Journal of Ethics, 9, 323-338.

Awwaliyah, I. (2013). Knowledge, attitudes and purchase intention of students to organic food: approach to theory of planned behavior (Thesis). Bogor: Bogor Agricultural University.

Bank for International Settlements. (1996). Implications for central banks of the development of electronic money. Retrieved from http://www.bis.org/publ/bisp01.pdf. 
Beck, L., \& Ajzen, I. (1991). Predicting dishonest actions using the theory of planned behavior. Journal of Research in Personality, 285-301.

Chang, M. K. (1998). Predicting unethical behavior: A comparison of the theory of reasoned action and the theory of planned behavior. Journal of Business Ethics, 17 (16), 1825-1834. doi: 10.1023 / A: 1005721401993.

Engel, J. F., Blackwell, R. D., \& Miniard, P. W. (1994). Consumer Behavior (Volume 1, Ed 6th). Budijanto, translator. Jakarta, Indonesia: Binarupa Script. Translation of Consumer Behavior (6th ed.).

Harding, T. S., Matthew, J., Mayhew, Cynthia, J., Finelli and Donald D. Carpenter. 2007. The Theory of Planned Behaviour as a Model of Academic Dishonesty in Engineering and Humanities undergraduates, Ethics \& Behaviour, 225-279.

Harrison, D. A., Mykytyn, P. P., \& Reimenschneider, C. K. (1997). Executive decisions about adoption of information technology in small business: Theory and Empirical Test. Information Systems Research, 8 (2), 171-195. doi: 10.1287 / isre.8.2.171.

Hatta, J. A. (2010). Factors considered by customers to adopt online banking service system (Thesis). Faculty of Economics, University of Proclamation 45. Yogyakarta.

Hidayat, A., et al. (2006). Efforts to Improve the Use of Non-Cash Payments Through Development of E-Money. Jakarta, Indonesia: Bank Indonesia.

Indriastuti, M. (2014). Influencers E-Money In Banking Sector. South East Asian Journal of Contemporary Business, Economics and Law, 4.

Jogianto, H. M. (2007). Keperilakukan Information System (Revision ed.). Yogyakart, Indonesiaa: CV Abdi Offset.

Kuningsih, and Reni, S. (2013). Factors that influence the intention of accounting students for a career as a professional accountant (Thesis). Semarang: Undergraduate Program Faculty of Economics and Business, University of Diponegoro.

Mowen, J. C, \& Minor, M. (1998). Consumer Behavior. New York, NY: Prentice Hall Inc.

Purnama, A. C. (2012). Analysis of the effect of the appeal of the promotion, perceived ease of use, perspsi use, persespsi expediency and price of the buying interest standalone e-toll card (A case study on the toll road users in the city of Semarang (Thesis). University Diponoogoro.

Stone, T. H., Jawahar, I. M., \& Kisamore, J. L. (2007). Predicting Academic Dishonesty: Theory of Planned Behavior and Personality. ASAC 2007 Ottawa, Ontario.

Taylor, S., \& Todd, P. A. (1995). Understanding information technology usage: A test of competing models. Information Systems Research, 6 (2), 144-176.

Yang, S. C. (2012). Attitudes and behaviors related to academic Dishonesty: A survey of Taiwanesse graduate students. Ethics and Behavior, 22 (3), 218237. 